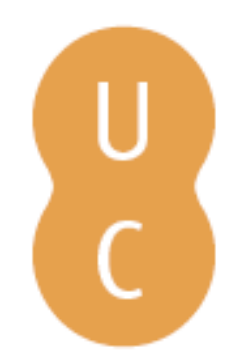

\title{
pompalina
}

\section{O encontro do velho continente com o novo mundo na carta a el-Rei Dom Manuel sobre o achamento do Brasil}

\author{
Autor(es): $\quad$ Soares, María Luisa de Castro \\ Publicado por: Imprensa da Universidade de Coimbra \\ URL \\ persistente: URI:http://hdl.handle.net/10316.2/38957 \\ DOI: $\quad$ DOI:http://dx.doi.org/10.14195/978-989-26-0395-7_11 \\ Accessed : $\quad$ 26-Apr-2023 16:23:09
}

A navegação consulta e descarregamento dos títulos inseridos nas Bibliotecas Digitais UC Digitalis, UC Pombalina e UC Impactum, pressupõem a aceitação plena e sem reservas dos Termos e Condições de Uso destas Bibliotecas Digitais, disponíveis em https://digitalis.uc.pt/pt-pt/termos.

Conforme exposto nos referidos Termos e Condições de Uso, o descarregamento de títulos de acesso restrito requer uma licença válida de autorização devendo o utilizador aceder ao(s) documento(s) a partir de um endereço de IP da instituição detentora da supramencionada licença.

Ao utilizador é apenas permitido o descarregamento para uso pessoal, pelo que o emprego do(s) título(s) descarregado(s) para outro fim, designadamente comercial, carece de autorização do respetivo autor ou editor da obra.

Na medida em que todas as obras da UC Digitalis se encontram protegidas pelo Código do Direito de Autor e Direitos Conexos e demais legislação aplicável, toda a cópia, parcial ou total, deste documento, nos casos em que é legalmente admitida, deverá conter ou fazer-se acompanhar por este aviso.

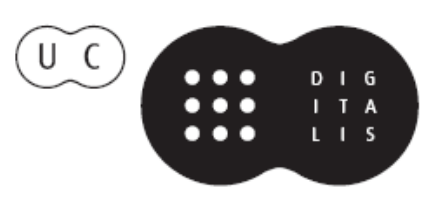


Nair de Nazaré Castro Soares

Santiago López Moreda

Coordenação

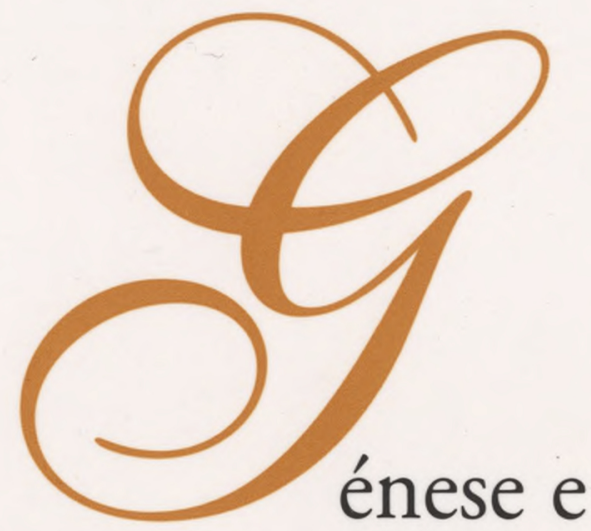

Consolidação da Ideia de Europa

Vol. IV

Idade Média e Renascimento

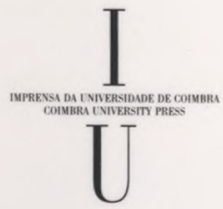

- COIMBra 2009 


\title{
O ENCONTRO DO VELHO CONTINENTE COM O NOVO MUNDO NA CARTA A EL-REI DOM MANUEL SOBRE O ACHAMENTO DO BRASIL
}

\author{
MARIA LUÍSA DE CASTRO SOARES \\ (Universidade de Träs-os-Montes e Alto Douro)
}

Os Descobrimentos e o monopólio do comércio com o Oriente, associados ao deslumbramento perante os "mimos Indianos" (Miranda, 1977: 52), envolvem Portugal numa "atmosfera de heroísmo ideal" (Cortesão 1967a: 38) favorecedora do orgulho dos Portugueses (Soares 2003: 554). Os vários relatos da literatura quinhentista revelam, na verdade, uma euforia nacional generalizada, devido aos sucessos das descobertas (Soares 1999: 91), que representam para Portugal um período de mudança, no sentido da prosperidade (Bernardes 1999: 369-463). Esta reflecte-se em todos os domínios do saber, de tal modo que, "durante a primeira metade do século XVI, ninguém excede na ciência geográfica, na astronomia náutica, na hidrografia ou nos estudos de matemática aplicada à navegação, um Duarte Pacheco, um D. João de Castro ou um Pedro Nunes" (Cortesão 1983: 61).

Movida pelo espírito humanista do Renascimento, a empresa marítima dos Descobrimentos é, pois, um inegável contributo para o conhecimento do mundo e do homem, encarado como fautor do seu próprio destino:

Descobrindo os oceanos e a ciência para os navegar, os Portugueses não se limitaram a dar à civilização europeia o melhor instrumento de hegemonia sobre a Terra; abriram igualmente o caminho para a unificação da Humanidade (Cortesão 1983: 72).

A Europa é considerada, na época, como o continente da civilização superior e o cristianismo a religião a propagar por todo o globo (Soares 1999: 99- 
-129). Este sentimento de orgulho na cultura e nos valores europeus é encimado por Portugal, pioneiro no movimento expansionista e persuadido de ser,

...aqui, quase cume da cabeça

Da Europa toda o Reino Lusitano

Onde a terra acaba e o mar começa

E onde Febo repousa no oceano (Camões 1994: 3.20)

A consciência de Portugal como nação imperial e o valor ou grandeza dos feitos praticados pelos Portugueses modelam assim a mentalidade nacional. Efectivamente, os Descobrimentos e a "maneira de ver a nossa acção além dos mares penetra profundamente nos espíritos" (Dias 1982: 18). Mas, por outro lado, sobressai um deslumbramento novo-riquista ou mundano e a imagem de Lisboa como entreposto comercial. Lisboa é, na verdade, o "centro do mundo em expansão e da exploração comercial" (Soares 2003: 554), é a "rainha do oceano (...), pois é sob o seu domínio que (...) se processa a navegação em todo o Oriente e Ocidente" (Góis 1988: 29). A capital, pólo de desenvolvimento e florescimento das artes e ciências, acentua assim a sua macrocefalia, porque se torna numa das grandes cidades europeias, a nível populacional e de organização ou majestade arquitectónica:

a sua grandeza e magnificência são tamanhas que bem pode pedir meças a quaisquer das restantes cidades da Europa, tanto pelo número de habitantes como pela beleza e variedade dos edifícios (Góis 1988: 48).

A cidade, berço e placenta da cultura humanista, reflecte também a mundividência renascentista. Mas aquele aspecto que pode ser considerado o maior contributo Português para o Renascimento são os Descobrimentos, não apenas pelo florescimento nacional, mas porque dão a conhecer novos climas, paisagens, faunas, floras, homens de raças e costumes diversos, alargando o conhecimento do mundo e do homem. Passa a aceitar-se a ideia de variedade de raças, na uniformidade do género humano. Também a noção de natureza se amplia, ao desaparecer a velha concepção que contrasta a natureza do mundo com a do "anti-mundo". A natureza, típica ou exótica, é uma. Diverge apenas pela variedade, causada pelas diferenças climáticas, que no entanto não impedem a sobrevivência humana, como até então se acreditava. São crenças como esta que Duarte Pacheco Pereira vem fazer ruir, quando afirma, na sua obra Esmeraldo de situ orbis, a existência de erros no saber antigo:

Pompónio Mela no princípio do seu segundo livro e assim no meio do terceiro de situ orbis, e mestre João de Sacrobosco, inglês, excelente autor, na arte da astronomia, no 
fim do terceiro capítulo do seu Tratado da Esfera, cada um destes em seu lugar, ambos disseram que as partes da equinocial eram inabitáveis pela muita grande quentura do sol. De onde parece que segundo sua tenção aquela tórrida zona por esta causa se não podia navegar, pois que a fortaleza do sol impedia não haver aí habitação de gente. O que tudo isto é falso (Pereira 1954: 196).

Os sólidos conhecimentos de cosmografia dos homens de ciência como Duarte Pacheco Pereira ou Pedro Nunes - cosmógrafo-mor de El-rei D. João III, a partir de 1547 - dão hegemonia científica e cultural a Portugal e contraditam todo um ideário que povoava o imaginário medieval e era tido como pressuposto verídico.

Inúmeras são, na verdade, as lendas medievas que povoam o mundo de monstros imaginários e inverosímeis. Disso damos exemplo, através de uma imago mundi de Pierre d'Ailly, a propósito da Ásia:

\begin{abstract}
Nas Montanhas do Oriente, já para além da oikoumenê, vivem os pigmeus, homens com dois côvados de altura, que se dedicam à caça dos grous. Esta gente tem três anos de gestação e morre aos oito anos de vida... Encontram-se também nestas regiões os macróbios, homens de doze côvados que combatem os grifos... Vêem-se, igualmente, bárbaros que matam os pais já velhos e os comem. Quem se recusa à prática deste costume é por eles considerado ímpio. Outros comem o peixe cru e bebem a água salgada do mar. Certos monstros humanos têm os pés no sentido de diante para trás e com oito dedos; outros têm cabeça de cão e peles de besta, ladrando como os cães. Há mulheres, nessas paragens, que procriam uma só vez, e os filhos, brancos à nascença, tornam-se negros na velhice a qual, aliás, não ultrapassa a duração de um estio. Outras há porém que engravidam cinco vezes, mas cujos filhos não vivem mais de oito anos. Há homens com um só olho, chamados arimaspos, e cinocéfalos chamados ciclopes. Tendo apenas um pé, correm no entanto com a velocidade da brisa, e quando se sentam no chão, abrigam-se do sol levantando a planta do pé... Perto do lugar onde nasce o Ganges, há homens que vivem apenas do odor de um determinado fruto, o qual por isso mesmo levam consigo quando viajam; se acaso cheiram um mau odor, morrem logo (Dias 1973:153-154).
\end{abstract}

Da correcção de um conjunto de fantasias imaginosas como esta, e de outras congéneres, sobre a geografia natural e o género humano, surge o espírito científico moderno, resultante da expansão portuguesa. Quando por toda a Europa Ocidental alastra o culto da Antiguidade, os Portugueses abrem a questão dos antigos e dos modernos, ao defenderem a superioridade destes últimos, pela certeza do saber experimental. Lembramos, a propósito, outro texto de Duarte Pacheco Pereira, onde o autor, depois de se opor a ao espírito medieval dos seus "antigos antecessores" e de "outros muito mais antigos 
doutras estranhas gerações", exalta nos modernos o saber experimental e o conhecimento científico derivado dos descobrimentos:

E como quer que a experiência é madre das cousas, por ela soubemos radicalmente a verdade (Pereira 1954: 196)

Esta frase pode ser considerada como um lema do espírito científico moderno, por ser reassumida por outros grandes nomes das ciências da cultura e da literatura da época. N'Os Lusíadas de Luís de Camões, este é o princípio que sobressai, quando o épico afirma: "Vi, claramente visto" (Camões 1994: 5.18) e "Eu o vi certamente (e não presumo / Que a vista me enganava)" (Idem, 5.19).

Neste contexto de actividade científica, experimental e expansionista portuguesa, inscreve-se a Carta a el-rei dom Manuel sobre o achamento do Brasil de Pêro Vaz de Caminha, a qual faz parte do coro generalizado que perpetua o "Século de Ouro" Português (Serrão 1988: 333). Na verdade, ao descrever, de certa forma espantado e maravilhado, a fauna, a flora e a realidade humana que vê, Pêro Vaz de Caminha faz do seu texto um espaço para a aferição de duas culturas diferentes: a do Velho e a do Novo Mundo. No texto epistolar, sobressai já a aceitação da relatividade cultural, no reconhecimento da diversidade (Dias 1982: 179), própria do humanista e homem de acção. Assim, a Carta pode ser considerado uma crónica de viagem, um contributo para o conhecimento do mundo e deve interpretar-se como uma forma de conhecer a "mentalidade de finais do século XV e dos seus reflexos na concretização de uma antropologia possível" (Albuquerque 1994: 179).

A literatura dos Descobrimentos não se limita, na verdade, a fazer uma descrição da fauna e da flora do Novo Mundo, apresenta também a imagem do Outro. As descrições do habitante do Novo Mundo são a prova da uniformidade do homem no globo terrestre, embora seja admissível a variedade de etnias e de costumes. Assim, esta literatura, em que a Carta de Caminha se inclui, deve ser vista como espaço de divulgação da existência de uma humanidade diversa e ainda um contributo para o desabamento de ideias como a da existência de seres disformes, ainda que o Outro nem sempre seja compreendido. O Outro pode ser, na verdade, para o navegador, para o homem soldado e para o escritor, o habitante "das terras viciosas/ de África e de Ásia" (Camões 1994: 1.2), ou o crente de Maomé, o inimigo da fé, contra o qual a guerra será justa (Soares 1999: 111). Nestes casos - e para a mentalidade da época - se a violência existir, é justificável, pois o homem Português é "o aventureiro e (o) santo" (Cortesão 1965: 73), uma espécie de miles cristianus, cavaleiro do sobrenatural, com a missão cumprir a vontade divina e de implantar o reino de 
Cristo na terra (Soares 1999: 99-129). Este ideal político, que tudo subordina ao catolicismo, revela alguma parcialidade e incompreensão do Outro, quando se trata do infiel. Apesar disso, conhecida como é a nossa capacidade de miscigenação, não se trata aqui de xenofobia, mas de alguma intolerância religiosa. Em contrapartida, o Outro, quando se fala do indígena, é encarado com interesse, respeito e é associado, por vezes, ao estado de pureza original. É esta imagem do indígena, como representante da Idade do Ouro, que é expressa por missionários e homens com alto sentido humanista, defensores da dignitas hominis, de que é exemplo Pêro Vaz de Caminha.

A sua Carta, "considerada a certidão de nascimento do Brasil" (Machado 1996: 95), além de ser um documento que marca o encontro entre o Velho e o Novo Mundos, é ainda tradutora das feições da expansão portuguesa e do perfil do humanista seu criador que, sendo "filho duma daquelas democracias urbanas, tão características da Europa medieval, (...) aprendeu nessa escola o sentido da tolerância, da dignidade humana e da compreensão, ainda hoje tão dificil, dos homens de outra raça e, no seu caso, de outra idade" (Cortesão 1967: 13).

Escrita no ano de 1500 , no território recém descoberto, a Carta tem essencialmente um carácter informativo. De facto, o escrivão da armada de Pedro Álvares Cabral visa dar a notícia ao rei do "achamento" de uma nova região. Embora saiba que muitas serão as cartas a fazer-lhe chegar tal novidade, Pêro Vaz de Caminha não deixa de humildemente redigir e enviar o seu testemunho:

Senhor, posto que o capitão-mor desta vossa frota e assim os outros capitães escrevam a Vossa Alteza a nova do achamento desta vossa terra nova, que ora nesta navegação achou, não deixarei também de dar disso minha conta a Vossa Alteza, assim como eu melhor puder, ainda que para o bem contar e falar o saiba por que todos fazer (Caminha 1974: 39).

Começada a escrever a 24 ou 26 de Abril, a Carta de Caminha narra, primeiramente e de modo breve, os sucessos da viagem e, depois, faz ao pormenor o relato de tudo quanto se passa, enquanto a frota permanece em terra nove dias. A Carta adquire, assim, a forma de diário e, por essa razão, retomam-se assuntos, acrescentam-se pormenores e emendam-se ideias.

Para levar a bom termo o seu texto, o escrivão afirma fazer um relato imparcial, ao registar somente aquilo que observa: "creia que por afremosar nem afear haja aqui de pôr mais do que aquilo que vi e me pareceu"(Idem, 31). Por isso, não abordará questões de técnica de navegação pois, para além de não o saber fazer, haverá quem disso fale ao rei: "Da marinhagem e singraduras do 
caminho não darei aqui conta a Vossa Alteza, porque o não saberei fazer e os pilotos devem ter esse cuidado" (Idem, 31-32).

Pêro Vaz de Caminha faz então a sinopse da viagem, desde "a partida de Belém" (Idem, 32), a 9 de Março de 1500, até ao momento em que aportam em terras de Vera Cruz. Do percurso da viagem, o escrivão realça a passagem pelas Canárias, por Cabo Verde e o desaparecimento, no dia 23 de Março à noite, da tripulação e da nau de Vasco d'Ataíde. Confessa-nos Caminha que, apesar dos esforços realizados "para o achar, a umas e a outras partes (...) não apareceu mais" (Idem, 33).

De seguida, começa o relato relativo ao dia de 21 de Abril, em que surgem sinais de terra. Relativamente ao decurso temporal entre o desaparecimento da nau de Vasco d'Ataíde e a visão de terra, Caminha é bastante omisso em informação, pois limita-se a afirmar que, depois de desistirem da procura da nau desaparecida, seguem em frente viagem, "de longo" (Idem, 33).

A intencionalidade da informação da descoberta é clara nas palavras de pormenor de Pêro Vaz de Caminha que, no dia 22 de Abril à tarde, juntamente com os outros Portugueses, todos avistam terra: "E neste dia, a horas de véspera, houvemos vista de terra" (Idem, 33). Reconhecem, de seguida, uma realidade outra, relativa à natureza vegetal e animal, ao verem as "ervas compridas, a que os mareantes chamavam botelho e assim outras, a que também chamam rabo d'asno" (Idem, 33) e as "aves, a que chamam fura-buchos" (Idem, 33). Quanto à paisagem, Pêro Vaz de Caminha releva "um grande monte, mui alto $\mathrm{e}$ redondo, e (...) outras serras mais baixas a sul dele e de terra chã com grandes arvoredos" (Idem, 33 -34). Ao monte, Pedro Álvares Cabral denomina "Monte Pascoal" e à terra, "Vera Cruz". Desta primeira visão do território desconhecido recém descoberto sobressai uma flora rica e frondosa, em nada agreste ou insuportável à vida.

Depois da visão da terra, da paisagem, da natureza vegetal e animal, a focalização, de progressiva proximidade, centra-se na realidade humana. Assim, a 23 de Abril, são avistados os primeiros indígenas: "E dali houvemos vista d'homens, que andavam pela praia" (Idem, 34), pelo que "o capitão mandou no batel, em terra, Nicolau Coelho" (Idem, 34).

Do relato de Caminha sabemos que, ainda mal o navegador se aproximava de terra, e já os íncolas a ele acudiam, de modo que, quando saiu da embarcação, "eram ali dezoito ou vinte homens" (Idem, 35). É, pois, Nicolau Coelho o responsável pela caracterização dos aborígenes de Vera Cruz. Como principais características, estes nativos possuem a tez escura e andam em completa nudez, aspectos que por si só asseguram aos Portugueses tratar-se de um 
povo diverso, alheio à civilização europeia. Além disso, revelam-se bastante pacíficos, uma vez que depõem os arcos que trazem, assim que lhes é solicitado: "Nicolau Coelho lhes fez sinal que pusessem os arcos, e eles os puseram"(Idem, 35). Este breve contacto inicial revela-se, todavia, pouco proveitoso, não só porque "não poude deles haver fala ou entendimento que aproveitasse" (Idem, 35), mas ainda "por o mar quebrar na costa"(Idem, 35). Apesar dos obstáculos linguísticos e marítimos, ainda houve tempo para uma troca de presentes:

Somente deu-lhes um barrete vermelho e uma carapuça de linho, que levava na cabeça, e um sombreiro preto. E um deles the deu um sombreiro de penas d'aves, compridas, com uma copazinha pequena de penas vermelhas e pardas, como de papagaio. E outro lhe deu um ramal grande de continhas brancas, miúdas, que querem parecer d'aljaveira, as quais peças creio que o capitão manda a Vossa Alteza (Idem, 35).

Esta troca de presentes é reveladora de que "toda a obra da expansão portuguesa é profundamente marcada pela fraternidade cristã, o amor naturalista da terra e uma efusiva simpatia humana" (Cortesão 1967: 13). Mas a isto acresce dizer que, presentear o Outro, era também um costume dos navegadores da época que contactavam com as populações, cuja simpatia e agrado queriam conquistar. Além disso, os produtos recebidos em troca eram enviados ao rei para que este conhecesse o que de novo existia nas terras descobertas.

Depois da troca de presentes, enunciada na Carta de Caminha, Nicolau Coelho "volveu às naus por ser tarde e não poder deles haver mais fala, por azo do mar" (Caminha 1974: 35).

Devido às condições climatéricas adversas: "A noute (...) ventou tanto sueste com chuveiros, que fez caçar naus" (Idem, 36), no dia 24 de Abril, a frota vai aportar à baía, com o objectivo de se abastecer de água e lenha. Agora, é Afonso Lopes o incumbido para sair num "esquife a sondar o porto dentro" (Idem, 37). Quando regressa, traz consigo "dous daqueles homens da terra, mancebos e de bons corpos" (Idem, 37), que Pedro Álvares Cabral acolhe "com muito prazer e festa" (Idem, 37). O convívio que então se desenvolve em torno dos dois homens, "o exame cultural dos dois indígenas" (Cortesão 1967: 94), faculta a Pêro Vaz de Caminha um retrato próximo e minucioso. A descrição que Caminha traça destes indígenas prende-se com elementos de comparação com o negro da Guiné, que conheceu por ter participado em outras expedições, e porque o africano está muito mais próximo da realidade e do padrão cultural dos íncolas de Vera Cruz do que o homem europeu, situado num outro estádio civilizacional. Além disso, só se pode comparar o que é de algum modo 
semelhante. A equiparação da civilização dos indígenas com a dos europeus seria absolutamente contrastiva.

A descrição etnográfica dos aborigenas começa então com elementos físicos: "A feição deles é serem pardos, maneira d'avermelhados, de bons rostos e bons narizes, bem feitos" (Caminha 1974: 37). São algo diversos dos negros, "de maçãs salientes, beiços grossos e proeminentes e sobretudo de nariz, largo e chato" (Cortesão 1967: 119). Igualmente, no que respeita aos cabelos, os dos aborígenes "são corredios" (Caminha 1974: 39), a contrastar com a carapinha crespa dos Guineenses. Muito próximos dos negros, na falta de vestuário, também os dois mancebos andam nús, "sem nenhuma cobertura, nem estimam nenhuma cousa cobrir nem mostrar suas vergonhas" (Idem, 37) e, à semelhança dos Guineenses islamizados, não são circuncisos. Andam "sem ter nenhuma maneira de cobrirem suas vergonhas, as quais não eram fanadas" (Idem, 42).

Pêro Vaz de Caminha, repetidas vezes ao longo da Carta, associa a nudez dos aborígenes e o seu estado civilizacional à pureza e inocência do paraíso adâmico, anterior ao pecado original: "E estão acerca disso (nudez) com tanta inocência como têm em mostrar o rosto" (Idem, 37-38).

A descrição dos íncolas de Vera Cruz não se cinge apenas ao corpo. Abarca ainda os enfeites que usam. Ao observar os dois homens e a sua comunidade, Pêro Vaz de Caminha descreve com minuciosa exactidão os adornos dos lábios: "Traziam ambos os beiços de baixo furados e metido por eles um osso branco do comprimento duma mão travessa e da grossura dum fuso d'algodão" (Idem, 38). Observa ainda os enfeites de penas ("um deles trazia por baixo da solapa, de fonte a fonte para detrás, uma maneira de cabeleira de penas d'ave") (Idem, 39) e a pintura dos corpos, ornamentações características dos índios:

Ali veríeis galantes, pintados de preto e vermelho e quartejados assim pelos corpos como pelas pernas, que, certo, pareciam assim bem (Idem, 56 ).

Além da visão comparativa dos caracteres físicos destes indígenas de Vera Cruz com os Guineenses, Caminha estabelece também uma comparação entre os objectos de ambas as culturas. Pela observação e pela experiência, sabe que as jangadas indígenas, a que chama "almadias", por comparação com as da Guiné, "não são feitas" do mesmo modo "como as que eu já vi; somente são três traves, atadas juntas" (Idem, 50). Também os arcos de que se fazem acompanhar ambos os grupos étnicos são diferentes. Os dos índios "são pretos e compridos e as setas compridas e os ferros delas de canas aparadas" (Idem, 68). Pelas descrições que pinta, Caminha demonstra possuir a "intuição de 
etnógrafo, a rara capacidade de definir uma humanidade nova e situá-la dentro da sua idade cultural própria" (Cortesão 1967: 121).

Depois de retratar os dois homens, Caminha faz-nos visualizar o cenário em que decorre todo o inquérito aos dois ameríndios e o espaço de encontro é também o do estranhamento de dois mundos:

O capitão, quando eles vieram, estava assentado em uma cadeira e uma alcatifa aos pés por estrado, e bem vestido, com um colar d'ouro mui grande ao pescoço. E Sancho de Toar e Simão de Miranda e Nicolau Coelho e Aires Correa e nós outros, que aqui na nau com ele imos, assentados no chão por essa alcatifa (Caminha 1974: 40).

Sobressai do exposto a apresentação de Pedro Álvares Cabral, que surge com toda a magnificência, adornado com um colar de ouro para chamar a atenção dos nativos e para saber se o metal existia nesta nova terra. Porém, os dois autóctones não mostram especial deferência ante o capitão, pois "não fizeram nenhuma menção de cortesia" (Idem, 40). Apesar disso, dão-lhe a perceber a existência de ouro e prata nas terras de Vera Cruz:

Um deles, porém, pôs olho no colar do capitão e começou d'acenar com a mão para a terra e depois para o colar, como que nos dizia que havia em terra ouro. E também viu um castiçal de prata e assim mesmo acenava para a terra e então para o castiçal, como que havia também prata (Idem, 40).

Os dois indigenas manifestam ainda familiaridade com um papagaio que Pedro Álvares Cabral levava, mas não fazem caso de um carneiro, animais por eles conhecidos. Revelam, porém, espanto e mesmo receio, quando lhes é mostrada uma galinha: "Mostraram-lhes uma galinha, quase haviam medo dela" (Idem, 40). Os Portugueses oferecem-lhes ainda comida e bebida, mas os petiscos não foram apreciados pelos dois indígenas:

Deram-lhes ali de comer pão e pescado cozido, confeitos, farteis, mel e figos passados; não quiseram daquilo quase nada. $\mathrm{E}$ alguma cousa, se a provavam, lançavam-na fora. Trouveram-lhes vinho por uma taça, mal the puseram a boca e não gostaram dele nada nem quiseram mais. Trouveram-lhes água por uma albarrada; tomou cada um deles um bocado dela e não beberam; somente lavaram as bocas e lançaram fora (Idem, 41).

Entretanto, "viu um deles umas contas de rosairo, brancas; acenou que thas dessem e folgou muito com elas"(Idem, 41). Mas o atractivo foi passageiro e o sono superior ao entusiasmo. Assim, após este pacífico encontro de culturas, os nativos, ali mesmo, "estiraram-se assim de costas na alcatifa, a dormir" (Idem, 42). 
$\mathrm{Na}$ Carta de Pêro Vaz de Caminha, é curioso o facto de não existir nenhuma referência a qualquer averiguação, ante os indígenas, sobre a existência de especiarias na terra recém descoberta, quando este era o principal objectivo económico da expedição de Cabral. Esta faceta vem reforçar a ideia de que "Pedro Álvares Cabral e os seus companheiros acreditavam ter aportado a uma terra nova, sem qualquer relação com a África e a Ásia" (Cortesão 1967: 97). Na verdade, os navegadores tiveram "mais do que a suspeita, a persuasão de ter descoberto, com a terra de Vera Cruz, um Novo Mundo, quer geográfico, quer humano" (Idem, 97).

No dia seguinte, a 25 de Abril, o capitão ordenou que "levassem aqueles dous homens e os deixassem ir com seu arco e setas" (Caminha 1974:42). E, além de restituídos à liberdade, foram presenteados com "uma camisa nova e uma carapuça vermelha e um rosairo de contas brancas d'osso, que eles levavam nos braços, e um cascavel e uma campanhia" (Idem, 42). Estes presentes tinham, certamente, como finalidade a conquista da simpatia dos nativos. Além disso, um degredado, Afonso Ribeiro, teve de acompanhar os dois homens, para que apurasse quais os hábitos e condições de vida dos índios: "para andar lá com eles e saber de seu viver e maneira" (Idem, 43). Os aborígenes, porém, apesar de colaborarem com os membros da armada portuguesa no transporte de água para as naus e na troca de presentes (Idem, 44), demonstram-se hesitantes e bastante intimidados com a presença de alienígenas no seu espaço familiar. Assim, não aceitam o degredado entre si: "e logo o tornaram a nós" (Idem, 44). Este procedimento é compreensível, porque "tudo era novo e estranho para os Portugueses que, por sua vez, eram estranhos para os nativos" (Morison 1940: 72). Há na verdade, em jogo, o encontro de duas imagens diferentes, uma "tomada de consciência (...) de um Eu em relação a um Outro, de um aqui em relação a um algures" (Machado; Pageaux 1981: 42), causador de mútuo estranhamento. Na verdade, toda a imagem do Outro implica necessariamente "uma distância significativa entre duas realidades culturais" (Idem, 43). É ainda num contexto de distanciamento em relação à alteridade que compreendemos a imagem que Pêro Vaz de Caminha tem das mulheres indígenas, que vê pela primeira vez, nesse mesmo dia de libertação dos dois nativos. Também em comparação contrastiva com as Guineenses, dirá que elas têm os "cabelos muito pretos, compridos, pelas espáduas" (Idem, 45) e andam nuas, tal como os homens. E como o distanciamento não implica necessariamente rejeição, na descrição de Caminha, percebe-se uma certa atracção pela figura feminina da indígena, que causaria inveja a muitas mulheres Portuguesas:

E uma daquelas moças era toda tinta, de fundo a cima, daquela tintura, a qual, certo, era tão bem feita e tão redonda na sua vergonha, que ela não tinha, tão graciosa, que a 
muitas mulheres de nossa terra, vendo-lhe tais feições, fizera vergonha, por não terem a sua como ela (Idem, $46-47$ ).

No dia seguinte, a 26 de Abril, que sabemos ser "domingo de Pascoela", os navegadores Portugueses assistem à primeira missa em terras de Vera Cruz: "determinou o capitão d'ir ouvir missa e pregação naquele ilhéu" (Idem, 48). Realiza-a o padre frei Henrique Soares e é "ouvida por todos com muito prazer e devoção" (Idem, 49). É curioso notar que a ela assistem também uma série de nativos, que "andavam folgando e olhando-nos, e assentaram-se" (Idem, 50).

Nesse mesmo dia, todos os capitães da armada se reúnem e decidem enviar a Portugal alguns homens no navio dos mantimentos, a fim de informar o rei do achamento de tal terra:

Assim a todos nos parecia ser bem mandar a nova do achamento desta terra a Vossa Alteza pelo navio dos mantimentos (Idem, 52-53).

Esta tomada de decisão permite-nos considerar que a descoberta de Vera Cruz não terá sido casual, uma vez que "o capitão-mor contava com plena aprovação de D. Manuel, pois o desvio dum dos navios contrariava abertamente as instruções reais" (Cortesão 1967: 100). E, embora tenham ainda ajuizado sobre a captura de dois indígenas para enviarem ao rei, optam antes por deixar ali dois degredados, pois, melhor que aqueles, estes poderiam dar informação válida sobre a nova terra e suas riquezas: "muito melhor informação dariam dous homens destes degradados que aqui deixassem do que eles dariam"(Caminha 1974: 53).

O encontro do Velho continente e do Novo Mundo, a convivência fraterna e já comercial com o Outro acontece ainda nesse dia, quando os Portugueses se misturam com a gente da terra, que troca os seus arcos e setas por carapuças de linho, sombreiros e outros objectos manufacturados. Desta confraternização desabrocha um ambiente de alegria, festa e mesmo dança, que tem como principal responsável a iniciativa de Diego Dias, que levou consigo um "gaiteiro":

Passou-se então além do rio Diego Diis, almoxarife que foi de Sacavém, que é homem gracioso e de prazer, e levou consigo um gaiteiro nosso, com sua gaita, e meteu-se com eles a dançar, tomando-os pelas mãos. E eles folgavam e riam e andavam com ele mui bem, ao som da gaita (Idem, 58).

É, porém, neste ambiente de festa que os aborígenes mostram, pela primeira vez, estranheza, "uma esquiveza como monteses" (Idem, 58). Na verdade, não permitem demasiada aproximação aos navegadores, à qual reagem 
com desconfiança inquieta, ao tentarem escapar-se "como pardais do cevadoiro" (Idem, 59). Ao serem considerados montesinhos, verdadeiros pássaros bravios, os íncolas não são compreendidos pelo estranho, que não devia, afinal, invadir a identidade, responsável pela estabilização e localização do sujeito.

Os homens tomam consciência de si próprios, ao medirem as diferenças que os singularizam, mas é preciso também respeitá-las. E o facto é que os Portugueses - primeiro, descobridores, depois, colonizadores - tomam a Europa e a pátria portuguesa como modelos de civilização, com normas de vida social superior. E esta parcialidade acusadora de alguma incompreensão do Outro é também perceptível, no momento em que Caminha traça a primeira súmula relativa aos nativos observados, ao considerá-los "gente bestial e de pouco saber" (Idem, 60). Acrescenta ainda que os índios não teriam "casas nem moradas" (Idem, 60), logo, viveriam ao ar livre, à semelhança de "aves ou alimárias monteses" (Idem, 60), facto que a experiência posterior desmentirá.

Depois desta visão animalesca e redutora, na perspectiva do leitor actual, mas compreensível no contexto do século XVI, Pêro Vaz de Caminha conclui que os nativos são belos, de aspecto limpo e saudável: "são tão limpos e tão gordos e tão formosos" (Idem, 60).

No dia seguinte, a 27 de Abril, a proximidade dos indígenas permite ao escrivão fazer pormenorizadas considerações etnográficas, sobretudo, respeitantes aos adornos dos lábios e às pinturas do corpo dos indígenas. Nesse dia, o escrivão percebe e explica, com visualismo e minudência, a origem da tintura que estampa os seus corpos:

Traziam alguns deles uns ouriços verdes d'árvores que, na cor, queriam parecer de castanheiros, senão quanto eram mais e mais pequenos. E aqueles eram cheios d'uns grãos vermelhos pequenos, que, esmagando-os entre os dedos, faziam tintura muito vermelha, de que eles andavam tintos. E, quanto mais se molhavam, tanto mais vermelhos ficavam (Idem, 63).

Como quem anuncia o que vê à medida que vai vendo, Caminha explica, nesse mesmo dia, o motivo pelo qual os dois nativos capturados no dia 24 não tinham comido nem bebido, quando lhes foi ofertado. É que a alimentação característica do Novo Mundo recém descoberto é diferente da portuguesa, pois consiste principalmente em "muito inhame e outras sementes, que na terra há, que eles comem" (Idem, 65). Mas a grande correcção do dia, aos juízos prévios de Caminha, é experienciada por Afonso Ribeiro e outros dois degradados que, por ordem do capitão, tiveram de "andar lá entre eles" (Idem, 63). Contrariamente à hipótese de Caminha, colocada no dia anterior, a verificação indica claramente 
que os nativos têm grandes casas de madeira, sem quaisquer compartimentos, com esteios e, de esteio a esteio, redes atadas onde estes descansam:

(...) foram bem uma légua e meia a uma povoação de casas, em que haveria nove ou dez casas, as quais diziam que eram tão compridas cada uma como esta nau capitana. E eram de madeira, e das ilhargas, de tábuas, e cobertas de palha; de razoada altura e todas em uma só casa, sem nenhum repartimento. Tinham dentro muitos esteios e d'esteio a esteio uma rede, atada pelos cabos em cada esteio, alta, em que dormiam, [...] em cada casa, se acolhiam trinta ou quarenta pessoas (Idem, 63-64).

Uma vez que procura traduzir de forma objectiva a realidade, a Carta - simultaneamente crónica de viagem (Albuquerque 1994: 179) e "fonte documental" (Serrão; Marques 1992: 57)- obedece, genericamente, ao modelo de focalização externa (Reis; Lopes 1987: 162-164) e o seu narrador "só vê o que um espectador hipotético veria" (Bal 1977: 37). Mas, porque vai sendo redigida durante os vários dias, à medida que os contactos entre marinheiros e nativos se vão desenvolvendo e se vão recolhendo as informações, o ponto de vista pictórico do focalizador sobre os nativos, a terra e os acontecimentos pode mudar, de acordo com o conhecimento aprofundado da realidade. Aqui, a perspectivação interna funciona em alternância com a externa, o ponto de vista individual joga com a objectividade, que raras vezes é obscurecida. Assim, tomamos conhecimento de que, no dia 28 , os marinheiros vão a terra "dar guarda de lenha e lavar roupa" (Caminha 1974: 66) e esculpir uma grande cruz que, a 1 de Maio, irão erguer na praia: "faziam dous carpinteiros uma grande cruz" (Idem, 66). Ao longo deste dia, é notória uma maior familiaridade entre os nativos do Novo Mundo e os navegadores, representantes do Velho continente europeu:

Era já a conversação deles connosco tanta, que quase nos torvavam ao que haviamos de fazer (Idem, 67).

Uma vez mais, os indígenas manifestam uma grande solicitude, ao ajudarem "a acarretar lenha e meter nos batéis e lutavam com os nossos e tomavam muito prazer" (Idem, 66). Revelam-se também bastante interessados nos utensílios em ferro usados pelos carpinteiros, que observam com curiosidade e atenção, por não conhecerem o ferro:

Muitos deles vinham ali estar com os carpinteiros e creio que o faziam mais por verem a ferramenta de ferro, com que a faziam, que por verem a cruz, porque eles não têm cousa que de ferro seja e cortam sua madeira e paus com pedras feitas como cunhas, metidas em um pau, entre duas talas mui bem atadas e por tal maneira, que andam fortes, segundo os homens, que ontem a suas casas foram, diziam, porque lhas viram lá (Idem, 66). 
O desconhecimento do ferro e o emprego de utensílios de pedra é, de algum modo, definidor do estádio cultural dos indígenas. $\mathrm{E}$, tanto os aborígenes como Caminha e os navegadores compreendem, no dizer de Jaime Cortesão, a "distância que vai da Idade da pedra à dos metais" (Cortesão 1967: 124).

É ainda neste dia que o escrivão da armada vai prender-se na observância da natureza, sobretudo na fauna abundante e variada, representada principalmente pelas aves, das quais sobressaem os papagaios:

Enquanto andávamos nesta mata a cortar lenha, atravessaram alguns papagaios por essas árvores, deles, verdes, e outros, pardos, grandes e pequenos, de maneira que me parece que haverá nesta terra muitos, mas eu não veria mais que até nove ou dez. Outras aves, então, não vimos; somente algumas pombas seixas e pareceram-me maiores, em boa quantidade, que as de Portugal. Alguns diziam que viram rolas, mas eu não as vi, mas, segundo os arvoredos são mui muitos grandes e d'infindas maneiras, não duvido que por esse sertão haja muitas aves (Idem, 67).

No que diz respeito ao dia 29 de Abril, Pêro Vaz de Caminha pouco diz, visto que os navegadores Portugueses não saem das embarcações. Apesar disso, distinguem bastantes indígenas na praia, "obra de trezentos, segundo Sancho de Toar, que lá foi" (Idem, 68) e dos quais trouxe dois para a nau, tratando-os atenciosamente: "mandou-os essa noute mui bem pensar e curar" (Idem, 69).

No dia seguinte, depois de uma semana de minuciosa observação, Pêro Vaz de Caminha faz mais uma sinopse relativa ao estádio primitivo dos indígenas que, apesar de possuírem casas e povoados, ainda não tinham alcançado o sedentarismo organizado:

Eles não lavram, nem criam, nem há aqui boi, nem vaca, nem ovelha, nem galinha, nem outra nenhuma alimária, que costumada seja ao viver dos homens; nem comem senão desse inhame que aqui há muito e dessa semente e fruitos que a terra e as árvores de si lançam (Idem, $73-74$ ).

Para acentuar uma cada vez maior intimidade dos íncolas de Vera Cruz em relação aos Portugueses ("E andavam mais mansos e seguros entre nós do que nós entre eles" - Idem, 71), Caminha anuncia, uma vez mais, um certo etnocentrismo cultural, quando se refere a uma aculturação dos nativos, que seriam facilmente influenciados pelos valores e costumes do Velho Mundo Português:

Comiam connosco do que thes dávamos e bebiam alguns deles vinho e outros não podiam beber, mas parece-me que, se lho avezarem, que o beberão de boa vontade (Idem, $70-71$ ). 
Se recordarmos os dois primeiros homens, levados às embarcações para o "exame cultural", notamos neste passo uma certa evolução, no sentido da aceitação da gastronomia portuguesa por parte dos nativos. Além disso, Caminha observa também a capacidade de assimilação dos indígenas, que imitam os gestos dos navegadores durante as cerimónias religiosas e verifica que:

Esta gente é boa e de boa simplicidade e imprimir-se-á ligeiramente neles qualquer cunho que thes quiserem dar (Idem, 72).

A reforçar a capacidade de adaptação dos íncolas de Vera Cruz (Puga 2003:209, Pêro Vaz de Caminha aponta já ao monarca o papel civilizador que Portugal poderá exercer neste povo e o fácil cumprimento do ideal político imperial manuelino, que visa subordinar o globo ao catolicismo (Soares 1999: 32-33):

E, portanto, Vossa Alteza, pois tanto deseja acrescentar na santa fé católica, deve entender em sua salvação; e prezará a Deus que, com pouco trabalho será assim (Idem, $72-73$ ).

Fica aqui a ideia de que os Portugueses pretendiam dilatar a fé, além do império, ou a expansão sob o signo de uma missão: a de evangelizar, a de cristianizar, que o mesmo é dizer a missão de civilizar, dado que, na época, não se concebia a civilização fora do cristianismo. O papel civilizador dos Portugueses consiste, assim, "no trazer dos índios à luz da civilização, isto é, do cristianismo e do conhecimento duma sociedade produtiva e sedentarizada" (Barreto 1983: 180). Mas, ao lado deste ideal, figura sempre a vertente económica dos Descobrimentos: "até agora não pudemos saberr que haja ouro, nem prata, nem nenhuma cousa de metal, nem de ferro; nem lho vimos" (Caminha 1974: 82).

No primeiro dia de Maio, a presença portuguesa é assinalada com a implantação de uma cruz "acima do rio, contra o sul, onde nos pareceu que seria melhor (...) para ser melhor vista" (Idem, 77). O ritual de "chantar a cruz" (Idem, 77), acompanhado de missa e de outras cerimónias religiosas, é seguido de perto por dezenas de indígenas que procuram imitar o comportamento dos navegadores Portugueses, durante as cerimónias religiosas: "tornaram-se assentar como nós. [...] eles se puseram todos assim como nós estávamos" (Idem, 78). Este facto impressiona favoravelmente Pêro Vaz de Caminha e reforça as suas esperanças de que os nativos venham a ser baptizados:

$\mathrm{E}$, segundo o que a mim e a todos pareceu, esta gente não lhes falece outra cousa para ser toda cristã que entenderam-nos, porque assim tomavam aquilo que nos viam fazer, 
como nós mesmos, por onde pareceu a todos que nenhuma idolatria nem adoração têm. E bem creio que, se Vossa Alteza aqui mandar quem mais entre eles de vagar ande, que todos serão tornados ao desejo de Vossa Alteza. E para isso se alguém vier, não deixe logo de vir clérigo para os baptizar, porque já então terão mais conhecimento de nossa fé pelos dous degradados que aqui entre eles ficam, os quais ambos hoje também comungaram (Idem, 80 -81).

Antes de concluir a sua Carta, Caminha faz um balanço de tudo que viu e das expectativas que criou relativamente à nova terra. Assim, ao mencionar a finalidade primeira desta expedição, o escrivão refere que não pôde saber se em terras de Vera Cruz há ouro, prata, ferro ou qualquer outro metal. No que diz respeito à geografia, o escrivão não revela qualquer certeza quanto à sua extensão:

Esta terra, Senhor, me parece que da ponta que mais contra o sul vimos até outra ponta que contra o norte vem, de que nós deste porto houvemos vista, será tamanha, que haverá nela bem vinte ou vinte cinco léguas por costa (Idem, $81-82$ ).

Acrescenta ainda que a quantidade de águas naquela terra é indicadora de um aproveitamento agrícola vantajoso: "querendo-a aproveitar, dar-se-á nela tudo por bem das águas que tem" (Idem, $82-83$ ). No que respeita ao clima, Pêro Vaz de Caminha compara Vera Cruz à região portuguesa de Entre-Douroe-Minho: "A terra, porém, em si, é de muito bons ares, assim frios e temperados como os d'Antre Doiro e Minho" (Idem, 82).

Para além de manifestar mais uma vez o desejo de que os autóctones sejam convertidos - "Mas o melhor fruito que nela se pode fazer me parece que será salvar esta gente" (Idem, 83) -, Caminha não deixa de referir-se à importância da terra como escala na navegação para a Índia: "E que aí não houvesse mais que ter aqui esta pousada para esta navegação de Calecute" (Idem, 83).

A Carta termina, tal como começa, de forma humilde, com um pedido de Pêro Vaz de Caminha para que o rei interceda por seu genro e "mande vir da ilha de S. Tomé Jorge d'Osoiro" (Idem, 83).

Da descrição que faz da nova terra, podemos sublinhar que o escrivão de Cabral viu no íncola de Vera Cruz uma nova identidade cultural, muito próxima do primitivismo. Assim, comparativamente com civilização europeia, esta nova realidade humana e cultural é por ele considerada claramente inferior, logo, caberia aos Portugueses uma acção civilizadora e evangelizadora.

Efectivamente, embora Caminha tenha o propósito expresso de ser objectivo, o certo é que a sua Carta deixa claro um certo etnocentrismo 
cultural. O Outro, enquanto ser humano diferente, é descrito através de uma analogia com o africano Guineense. Mas o modelo de referência tomado como ideal é o homem pertencente à civilização europeia, em comparação com o qual o íncola sai obviamente inferiorizado. É esta auto-concepção de superioridade portuguesa que permite aos navegadores raptarem dois homens do universo do Outro civilizacional para exercer neles um "exame cultural". Os dois mancebos trazidos para as embarcações funcionam como a primeira fonte de informação sobre o Novo Mundo. A partir de então, todo o contacto com o Outro é pautado por objectivos económicos e religiosos. As próprias descrições dos indigenas traçadas por Caminha reenviam, constantemente, para uma facilidade de aculturação e de absorção da civilização e da cultura portuguesas. Assim sendo, o texto de Caminha é dominado por "uma etnologia prática capaz de cimentar melhor a utilidade da comunicação civilizacional" (Barreto 1983: 178) que os Portugueses procuram sempre estabelecer e que culmina na colonização.

Pêro Vaz de Caminha, como homem do Velho Mundo, embora humanista e imbuído de uma mentalidade renascentista, dá então uma visão do novo homem e da nova terra, em função da curiosidade e da mentalidade portuguesa e europeia. Por isso, muitas vezes, interpreta os gestos dos indigenas, de acordo com o seu desejo: "Isto tomávamos nós assim por o desejarmos" (Caminha 1974: 41). E o desejo ou objectivo do homem Português incide no vector económico e no ideal de missionação. De facto, desde o primeiro contacto dos Portugueses com o novo homem, sobressai uma preocupação verdadeiramente cristã de "salvar esta gente" (Idem, 83). Na verdade, a difusão do catolicismo (religião verdadeira, a promover pelo descobridor) visa o reforço da identidade nacional portuguesa, a relação do Eu com o Outro e com o Alto. É por isso que os homens de acção de Quinhentos tentam incutir no Outro descoberto, com a vigência de novas leis, aquilo que concebem como uma maneira de viver melhor, num mundo de justiça e de ordem, regido pelos ideais do Velho Mundo europeu.

A Carta apresenta, enfim, uma imagem do Novo Mundo e do seu estádio de civilização. Vera Cruz é a nova terra recoberta de uma fauna e de uma flora exóticas, habitada por um homem novo, em estado primitivo, regido pelas leis da natureza e da inocência "que a d'Adão não seria mais quant'a em vergonha" (Idem, 81).

Embora Pêro Vaz de Caminha não refira a expressão "Novo Mundo", na Carta desenvolve-se esse conceito, "na sua parte mais transcendente - a humana" (Cortesão 1967: 126). Além disso, de modo mais implícito no plano do discurso, mas declarado na atitude dos descobridores, reconhecemos a 
mentalidade do Velho Mundo, dominada pela ânsia de descobrir o Outro, sem estreiteza de espírito, sem denegrir a alteridade, mas ainda de forma algo etnocêntrica. Também, o que aos olhos actuais aparece como moralmente injustificável, é perfeitamente legítimo no período áureo de uma nação que vai ganhando "plena consciência de si própria" (Cortesão 1995: 94). Os progressos científicos e os sucessos das descobertas territoriais acentuam, na verdade, a ideia de superioridade que caracteriza Portugal e a restante Europa. E este texto epistolar, porque descreve de forma pormenorizada a nova realidade fisica e sobretudo humana, deve ser encarado como mais um contributo para o alargamento da cosmovisão do Velho Mundo, que vê assim a sua civilização mais dilatada.

A Carta a el-rei dom Manuel sobre o achamento do Brasil, ao constituirse como um texto que revela um novo e diverso continente ao Velho Mundo, nos vários aspectos que se apresentam aos navegadores Portugueses, abarca os mais variados domínios do conhecimento e da cultura: a geografia, a religião, a ciência náutica, a botânica e a etnografia. E porque Pêro Vaz de Caminha não conhecia a verdadeira extensão territorial, opta pela generalização. A imagem global que se depreende do seu relato é, assim, a da variedade da natureza física desta terra, em termos de analogia referencial com os padrões do já conhecido. Relativamente à realidade humana, o Outro é encarado como alguém situado "num estágio primeiro de mundividência, numa caverna civilizacional que há-de abandonar devido ao papel dos Portugueses" (Barreto 1983: 180). O papel dos Portugueses será então o de trazer a civilização aos índios, ou seja, os valores e princípios do cristianismo e de uma sociedade produtiva e sedentarizada.

Em suma, a Carta, redigida para informar o rei da descoberta de uma nova região, é também um contributo para o alargamento da visão do mundo e é tradutora da "civilização moderna" (Barreto 1986: 87), no que esta tem de "transcendência total, metódica e sistemática dos universos culturais herdados" (Idem, 87). Nela, faz-se a descrição de uma nova terra recém descoberta e do homem novo, diverso, adâmico, do qual Pêro Vaz de Caminha revela uma imagem, que implica acolhimento e distanciação. O texto apresenta-se, assim, como "um manifesto múltiplo e polissémico tanto da notícia do Novo Mundo como do noticiário dos olhos do Velho Mundo europeu" (Barreto 1983: 171). O encontro pacífico do Outro não the dissolve ainda a identidade. Posteriormente, porém, com a colonização, perdurará a imagem da natureza incontaminada, mas desaparecerá a imagem do Outro, contaminado já pela aculturação. 
Pelo que ficou dito, podemos concluir que a Carta surge como um texto paradigmático da literatura quinhentista, cujo tema dominante é a expansão, a qual não seria possível sem a heroicidade dos Portugueses, representada no texto pela viagem (Seixo 1977) de Pedro Álvares Cabral. Efectivamente, com "a viagem de Cabral descobrira-se, pois, uma terra apetecida e que ficou a constituir o mais belo florão do ecumenismo Português" (Serrão 1988: 104). Além disso, a identidade sai fortalecida pelo diálogo com o Outro, sem o qual o $E u$ não se pode definir. O processo de autocompreensão só pode realizar-se através da alteridade, isto é, pela percepção e encontro com os valores do Outro, que vemos delineados por Pêro Vaz de Caminha.

$\mathrm{Na}$ Carta, estamos na verdade perante uma imagem eufórica do encontro entre o Velho continente e o Novo Mundo, com supremacia daquele sobre este, na focalização de Caminha. Mas, de sujeito individualista - consciente da superioridade dos valores e da cultura do Velho Mundo, centrado no ideal Português e europeu - passa a sujeito sociológico, que sabe reconhecer a importância da relação com outros "eus". Há, portanto, com o achamento do Brasil, que a Carta revela, um salto da entropia do Velho Mundo para a interacção com o Novo Mundo e a identidade do sujeito descobridor resulta enriquecida dessa relação com a alteridade. Embora permaneça o Português como civilizador e dominante, a sua postura é claramente modificada pelo diálogo contínuo com o mundo, a quem procura incutir os valores, sentidos e símbolos do Velho Mundo por si habitado e de que é o mediador operativo. 


\section{BIBLIOGRAFIA}

Albuquerque, Luís de (1994): Dicionário de História dos Descobrimentos Portugueses, Vol. I. Lisboa: Editorial Estampa.

BAL, M. (1977): Narratologie (Essais sur la signification narrative dans quatre romans modernes). Paris, Librairie KlincKsiecK.

BARRETO, Luís Filipe (1983, 2. ${ }^{\text {a }}$ ed.): Descobrimentos e Renascimento. Lisboa: Imprensa Nacional - Casa da Moeda.

- (1986): Caminhos do Saber no Renascimento Português. Lisboa: Imprensa Nacional Casa da Moeda.

Bernardes, José A. Cardoso, História Crítica da Literatura Portuguesa. Humanismo e Renascimento, Vol.II. Lisboa: Verbo, 1999.

CAminha, Pêro Vaz de (1974): Carta a el-rei dom Manuel sobre o achamento do Brasil. Lisboa: Imprensa Nacional - Casa da Moeda.

CAMÕES, Luís de (1994): Os Lusíadas. s/ 1.: Editora Ulisseia.

Coelho, Jacinto do Prado (1984, 3. ${ }^{\text {a }}$ ed.): Dicionário de Literatura, Vol. I. Porto: Figueirinhas.

CORTESÃo, Jaime (1965): O Humanismo Universalista dos Portugueses. Lisboa: Portugália Editora.

- (1967a): A Expedição de Pedro Álvares Cabral e o Descobrimento do Brasil. Lisboa: Portugália Editora.

- (1967): A Carta de Pêro Vaz de Caminha. Lisboa: Portugália Editora.

- (1983): A Expansão dos Portugueses na História da Civilização. Lisboa: Livros Horizonte.

DIAS, J. S. da Silva (1973): Os Descobrimentos e a Problemática Cultural do Século XVI. Coimbra.

Godinho, Vitorino Magalhães (1994): O Papel de Portugal nos Séculos XV e XVI-Que Significa Descobrir? Os Novos Mundos e o Mundo Novo. Lisboa: Editorial do Ministério da Educação.

Góıs, Damião de (1988): Descrição da Cidade de Lisboa. Lisboa: Livros Horizonte.

MACHADO, Álvaro Manuel (1996): Dicionário de Literatura Portuguesa. Lisboa: Editorial Presença.

MACHADO, Álvaro Manuel; Pageaux, Daniel-Henry (1981): Literatura portuguesa, literatura comparada e teoria da literatura. Lisboa: Edições 70.

Magalhães, Joaquim Romero (1998): Portugueses no Mundo do Século XVI. Lisboa: Comissão Nacional para as Comemorações dos Descobrimentos Portugueses.

MARGARIDO, Alfredo (1994): As surpresas da flora no tempo dos descobrimentos. Lisboa: ELO, D.L.

MARQues, Maria Lúcia Garcia (2003): "A escrita do Primeiro Olhar. Uma re-leitura do Roteiro de Álvaro Velho e da Carta de Pêro Vaz de Caminha". In Condicionantes Culturais da Literatura de Viagens, Vol. 2. Coimbra: Almedina: 45-87. 
Miranda, Sá de (1977): Obras Completas, vol.Il, Lisboa: Sá da Costa Editora.

Morison, S. E. (1940): As Viagens Portuguesas à América (Trad. Luís M. Maia Varela). Lisboa: Editorial Teorema.

PEREIRA, Duarte Pacheco (1954, $3^{\mathrm{a}}$ ed.): Esmeraldo de situ orbis (Introdução e anotações históricas de Damião Peres). Lisboa: Academia Portuguesa de História.

PINO, Firmín del; Lázaro, Carlos (coords.) (1995): Visión de los Otros y vision de si mismos. Descobrimiento o invención entre el Nuevo Mundo y el Viejo. Madrid: C.S.I.C.

PINTo, João da Rocha (1989): A viagem, Memória e espaço. Lisboa: Livraria Sá da Costa.

PuGA, Rogério Miguel (2003): "O Olhar através do género. A imagem do índio Brasileiro na Literatura Portuguesa de quinhentos". In Condicionantes Culturais da Literatura de Viagens, Vol. 2. Coimbra: Almedina: 177-229.

REIS, Carlos; Lopes, Cristina M. (1987): Dicionário de narratologia. Coimbra: Almedina.

SElxo, Maria Alzira (1997): A Viagem na Literatura. Mem Martins: Publicações Europa América.

SERrÃo, Joaquim Veríssimo (1988, 2." ed.): História de Portugal, Vol. III. Lisboa: Editorial Verbo.

Serrão, Joel e Marques, A. H. de Oliveira (1992): Nova História da Expansão Portuguesa - O Império Luso-Brasileiro (1500-1620). Lisboa: Editorial Estampa.

SIMÕES, Manuel (1985): A Literatura de Viagens nos Séculos XVI e XVII. Lisboa: Editorial Comunicação.

SOARES, Maria Luísa de Castro (1999): Dimensão profética e idealismo humano de dois poetas da espiritualidade portuguesa. Vila Real: UTAD.

- (2003): "Vida áulica e ideal do cortesão no Renascimento e em Damião de Góis". In: Damião de Góis na Europa do Renascimento. Braga: Publicações da Faculdade de Filosofia - Universidade Católica Portuguesa.

- (2007): Profetismo e Espiritualidade de Camões a Pascoaes. Coimbra: Imprensa da Universidade.

Ramalho, Américo da Costa (1983, 2. ${ }^{a}$ ed.): Estudos sobre o Século XVI. Lisboa: Imprensa Nacional - Casa da Moeda.

— (1997): Estudos sobre a Época do Renascimento. Lisboa: Fundação Calouste Gulbenkian.

RiBEIro, Cristina Almeida (1998): "Representações e mitificação do outro na Carta de Pêro Vaz de Caminha. In Biblioteca Virtual dos Autores Portugueses. Lisboa: Biblioteca Nacional. [Edição em CD-Rom]. 